\title{
Assessing the Effects of Demographic Characteristics on ICT and Indigenous Knowledge usage by Small Scale Farmers
}

\author{
Francis Yao Anyan \\ $\mathrm{PhD}$ Candidate at Open University of Malaysia (OUM) \\ Accra Institute of Technology (AIT) \& \\ Lecturer Kumasi Technical University \\ Mathematics and Statistics Department \\ P.O. Box 854 Kumasi \\ Godfred Frempong \\ CSIR-Science and Technology Policy Research Institute \\ P.O. Box CT 519 Accra
}

\begin{abstract}
Information and communication technologies (ICT) have been changing the way that actors like researchers, development agents, policy makers, and farmers share agricultural information and knowledge. The study investigated the effects of demographic characteristics on ICT and indigenous knowledge usage by small scale farmers from three (3) districts in Ghana. Data for the study were collected from both primary and secondary sources and analyzed using different quantitative and qualitative statistical procedures and methods. The study revealed that age has effect on agricultural indigenous knowledge required by small scale farmers. Also education has a significant effect of on the types of ICT tools and services used by small scale farmers and gender has no statistical significance effect of on the type of AIK practice by respondents.
\end{abstract}

Keywords: Indigenous Knowledge, Small Scale Farmers, I.C.T. Agriculture and Agribusiness

\section{Introduction}

As with other economic sectors, effective agricultural development requires access to information on all aspects of production, processing and marketing. A previous investigation by Zijp, (1994) proposes that ICT is now demonstrating the possibility to assume an important role in the delivery of valuable information to the agricultural sector in both developed and developing countries. There are various examples where access to enhanced production and market information has become important to small scale farmers who largely form part of the vulnerable group. The information might also include extension and research on adoption of new crop varieties, mechanization, pests and weed control, processing and the care of livestock. Further ICT allow information to be accessed at any time during the week or day. At the level of agribusiness, the value to a business of having access to ICT is potentially immeasurable.

Scoones and Thompson (1994); Van Veld-huizen et al. (1997), Mettrick (1993) stated in their studies that agricultural indigenous knowledge plays an important role in the developments of agriculture such as the domestication of crops and livestock, the development of animal traction, and the dissemination of species around the world. The study conducted in south-western Uganda by Hart \& Johann (2005) argues that indigenous or local knowledge appears to be important in achieving sustainable agriculture, especially regarding food security and is therefore important to the future of agricultural development programmes and strategies.

\section{Objective of the study}

The study has a broad objective to assess the effects of the demographic characteristics on the use of ICT and agricultural indigenous knowledge (AIK) by small scale farmers. The following specific objectives would be pursued by the study:

1.Describe the demographic characteristics of respondents,

2. Assess the effect of age on AIK usage,

3. Find out the effect of education on ICT usage

4. Identify the effect of gender on AIK usage by farmers. 


\section{Literature Review}

\section{ICT in Farming}

According to Warren (2003) some of the likely benefits to small scale farmers and those in agribusiness arising from acceptance of ICT include faster, easier access to records and accounts; help with complex decisions through decisionsupport systems; cheaper in communicating with others via the swift transmission of information in electronic form; and rapid access to a vast store of information through decision-support systems. Certainly, it is notable that Neven et .al (2005) include a cellular phone in a list of assets owned by farmers who supply supermarket chains in Kenya. The list includes others such as an irrigation system, refrigerator trucks and a packing shed among others.

Burgess and Pande (2005),Levine (2005) are of the view that ICT h a s had substantial impact in developing countries, as they are being utilized in the agricultural sector through ICT-enabled solutions for food and agricultural production. ICTs improve access to financial services of which a large body of theoretical and empirical literature suggests could have significant impacts on economic growth and poverty reduction in developing countries.

According to FAO (2006) technology and what can be accomplished with it has implications for rural communities and producers of all sizes, whether these are larger commercial producers who need to understand global market situations that affect them or subsistence producers concerned with local input markets. FAO, (2006) provides many examples of ICT applications in this domain, including uses in the application of chemical, fertilizers, herbicides and pesticides, as well as for efficient resource management such as livestock movement regulations. Pathways of development can include crop expansion and increased production where basic crop production is the dominant activity, and similar management strategies can be used in livestock farming. The use of feed supplements, specialized veterinary services and breeding services are other examples identified by the study.

ICTs also play an important role in facilitating agricultural growth through efficiency in market interactions and provide accessorial time information to enhance farmers' access to markets and prices through the use of trading platforms mediated through web/mobile applications (Driouchi et al., 2006). They allow people to obtain information immediately on a regular basis as compared to other information channels. It is argued that the utilization of ICTs, especially by using mobile technologies greatly reduces search costs, as stipulated by the search theory. In a study by Overa (2006) it was reveal that the revolution of mobile telecommunication in Ghana helped to reduce information asymmetry.

According to World Bank, (2007) and Savanna, (2010) some rural areas in Tanzania are making use of telecentres to access different information in various formats. These telecentres constitute the agricultural communication systems which are important because they facilitate sharing of information among stakeholders. Information is one of the key inputs to productivity growth (Anderson and Feder, 2007). The farmer's demand for information is seen as a productive input, and thus depending on how productive or useful the information is, the farmer is willing to purchase that input. Therefore, different delivery systems will have different values depending on the kind of information being delivered, (e.g. availability of inputs, new seed varieties, input prices, weather information, future prices, ways of using inputs etc.).

According to Jensen (2007) the introduction of mobile phones decreased price dispersion and wastage by facilitating the spread of information for fishermen in Kerala. This made markets more efficient and enhanced both consumer and producer welfare. Mobiles allow fishermen, particularly the more prosperous ones, to get timely price information and decide on the best place to land and sell their daily catch. Abraham (2007), who also looked at Kerala fishermen, found that the widespread use of mobile phones increased the efficiency of markets by decreasing risk and uncertainty, although it is noted that realizing potential efficiency depended on easy access to capital.

\section{ICT and Indigenous Knowledge.}

Nowadays, ICTs can help to document and disseminate indigenous knowledge. Pacheco and Abbagliati(2006) suggest that digital preservation and the promotion of indigenous knowledge provide a means for isolated communities (e.g. in Chile) to become part of the global information society. Indigenous knowledge (IK) faces possible extinction unless it is properly documented and disseminated (Nyumba, 2006). Depending on the availability and access, some indigenous groups have taken advantage of new technologies, including ICT's for example, by using digital video and audio recording devices and Internet technologies to capture, store and retrieve aspects of their arts and language (Oppenneer, 2010). By harnessing ICTs, these indigenous groups and local communities have thereby crossed the digital divide and are becoming part of the global information society. As Pacheco and Abbagliati (2006) indicate, having access to computers and the Internet is essential in order to be informed and be part of the world today. However, for those groups who have not been able to cross the digital divide, ICT's have marginalized indigenous communities even further. 
When it is introduced to indigenous groups it brings along mass media and global languages that can potentially conflict with local traditions. There is a further concern in that ICTs do not always operate in a manner that responds to the nature of IK. Landzelius (cited in Oppenneer, 2010) suggests this requires us to adopt a new paradigm, one that acknowledges that indigenization means not just enlisting ICT's to do things with tradition, but enlisting tradition to do things with ICT. Herselman and Britton (2004) indicate that successful participation is not practical when potential end users do not know what the alternatives actually are. ICT's therefore require a significant learning cycle and may have pre-conditions attached which may be forced onto users since the ICT investment is by donor organizations. Such conditions may result in the forced utilization of a particular selected ICT whereas an alternative ICT may have been more appropriate and yielded a significantly better adoption by the end-users. There is a need for indigenous users to assimilate and adapt chosen ICT ${ }^{\text {ee }}$ s to their own contexts. The inherent problem with ICT's is that while it may be good at preserving explicit indigenous knowledge, there is difficulty in how to treat tacit IK. Also Herselman and Britton (2004) revealed that the increased focus on modern ICT-based methods of information provision comes from the realization that they can play a major role in

i) Communicating knowledge and information to rural farmers,

ii) Delivering education and training modules to farmers at low cost,

iii) Improving smallholder farmers' access to markets and agricultural credit,

iv) Empowering farmers to negotiate better prices, and

v) Facilitating and strengthening networking among smallholder farmers.

\section{Role of demographic characteristics in technology adoption}

Demographic characteristics refer to the personal characteristics such as age, gender, educational level, religion and ethnic group. These characteristics play a critical role in the adoption of new technologies. In the study by Gefen \& Straub (1997); Morris \& Venkatesh, (2000) it was shown that gender plays an important role in technology. When men decide to use a technology, their decision is often strongly influenced by the perceived usefulness of the technology in comparison with others, while ease of use is the major variable influencing women's decisions. Gachukia (2012) in a study on influence of demographics on adoption of social media noted gender differences in the adoption of new technologies. The study noted that men's adoption of new technology was strongly influenced by their perception of usefulness while women were strongly influenced by their perceptions of ease of use. Additionally, the study notes that more males than females are likely to adopt to new technologies faster. Amongst the major issue that led to the slower adoption of new technologies was that females displayed more negative attitude towards computer based technology.

According to Baariu, (2015) those who adopts technological innovations early are typically younger in age, having higher incomes, better educated, and having higher social status. The study also revealed that age is a key demographic characteristic that influences the adoption of new technologies across diverse firms. The younger people in an organization are likely to have a higher perceived ease of use that leads to their increased adoption of new technologies. Abdelbary (2011) in a study on factors affecting adoption of biometric technology by five-star Egyptian hotel employees found significant differences in ease of use by age. Mulwa (2015) in a study on factors influencing adoption of ICT in service delivery by Kitui County Governments found that education levels had an impact on the adoption levels of ICT. This is because the education levels are often correlated with a higher exposure rate to computer usage which is critical in the adoption of new technologies.

\section{Methodology}

The study was carried out in the Kpando Municipal, Ada East and Asuogyaman Districts of Ghana. Data for the study were collected from both primary and secondary sources. Primary data were collected using structured questionnaire and administered to 985 respondents in the sampled districts. Items such as the demographic characteristics of the respondents, types of ICT and types of agricultural indigenous knowledge were covered by the questionnaire. The secondary data were obtained from published materials such as policy documents, districts annual reports, journals, and e-resources. Data was analyzed using different statistical procedures and methods. Descriptive statistical tools used to summarize and categorize the research data were frequency tables and percentages. Inferential statistical tools adopted for this study were, Chi-square analysis, Multivariate analysis of variance (MANOVA) and Factorial Anova.

\section{Results and Discussions}

Demographic Characteristics.

For the purposes of this study the demography characteristics are made up of gender, age and educational level. Below is the result from the study. 
Table 1: Demographic Characteristics.

\begin{tabular}{llcc}
\hline Demographic Characteristics & Frequency & $\begin{array}{c}\text { Percentage } \\
(\boldsymbol{\%})\end{array}$ \\
\hline Gender & Male & 402 & 41 \\
& Female & 583 & 59 \\
\hline \multirow{3}{*}{ Age(years) } & $20-30$ & 239 & 24 \\
& $31-40$ & 246 & 25 \\
& $41-50$ & 217 & 22 \\
& $51-60$ years & 142 & 15 \\
& above 60 years & 141 & 14 \\
\hline \multirow{3}{*}{ Educational Level } & No formal education & 334 & 34 \\
& Basic education/Middle School & 413 & 42 \\
& Secondary & 169 & 17 \\
& Tertiary & 68 & 7 \\
\hline
\end{tabular}

Source: Field study

From the table 1 it can be seen that females are in the majority (59\%) and $41 \%$ of the respondents are male. This shows that females are engaged in farming more than their male counterparts in the study area.

Also it can be seen from the tables that, majority of the respondents were between 20-40years and formed $49 \%$ of the sample. This age group is more economic active and constitutes almost half of the sample. The implication of this is that respondents in the study area are relatively young and therefore they should have more strength for farm work involving ICT and indigenous farming practices.

On education, $42 \%$ had basic education while $17 \%$ and $7 \%$ had secondary and tertiary education respectively with $34 \%$ with no formal education. This is an indication that majority of the respondents can read and write. The engagement of educated people in farming is an asset to technological adoption and its sustained use. Education polishes an individual, develops the intellect and makes him a wide user of resources.

ICT tools and services owned by small scale farmers.

In this study an attempt was made to establish the type of ICT tools and services owned by respondents. This would help in the establishment of the extent to which respondents use these ICT tools and services in their farming activities. Table 2 summarized the results obtained from the study.

Table 2: Ownership of ICT tools and services

\begin{tabular}{lll}
\hline ICTs tools and services & Frequency & $\%$ \\
\hline Computers & 37 & 4 \\
Internet & 15 & 2 \\
Email & 5 & 0.5 \\
CD-ROM databases & 0 & 0 \\
Geographic Information systems (GIS) & 0 & 0 \\
Telephone/Fax & 37 & 4 \\
Mobile phone & 763 & 78 \\
Television & 402 & 41 \\
Video & 162 & 16 \\
Radio & 787 & 80 \\
Precision Agriculture System & 0 & 0 \\
\hline
\end{tabular}

Source: Field study

As can be seen from the table above radio (80\%) and mobile phone (78\%) were the most available ICT tools to respondents. This confirms an earlier study by Chilimo (2008) who reported that most farmers used radio and cell phones frequently in four rural districts of Tanzania. Radio was more likely to have high use due to its low cost, use of local languages, as well as being an appropriate tool that fulfills farmers' needs. Akulloet al.,(2007) in their study found out that radio programmes were the major ICT channel used by farmers to acquire agricultural IK in Uganda. The findings also showed that mobile phones were becoming important communication medium mainly due to high ownership in the surveyed district. In Ghana this may be due to the fact these two are the main basic ICT used by the average Ghanaian. 


\section{Types of agricultural indigenous knowledge required for farming activities}

Respondents were asked to indicate agricultural indigenous knowledge that they require for their farming activities.

Table 3: Types of agricultural indigenous knowledge required by respondents.

\begin{tabular}{lll}
\hline Types of Knowledge & Frequency & \% \\
\hline Planting season & 642 & 65 \\
Pest Control & 572 & 58 \\
Crop processing & 477 & 48 \\
Shifting cultivation & 452 & 46 \\
Improving soil fertility & 537 & 55 \\
Information on rainfall pattern & 503 & 51 \\
Market Information & 574 & 58 \\
Information on different agricultural program & 389 & 40 \\
Soil classification & 429 & 44 \\
Irrigation & 337 & 34 \\
Agricultural tools & 443 & 45 \\
Land preparations & 602 & 61 \\
\hline
\end{tabular}

Source: Field study

It is evident from table 3 that, respondents required various types of agricultural indigenous knowledge for their farming activities. Planting season was identified by the majority $(65 \%)$ of the respondents as the type of knowledge the required most. Additionally, knowledge on land preparation (61\%), market information (58\%) and improving soil fertility $(55 \%)$ were required by respondents. The study also shows that knowledge on irrigation (34\%) was the least required by respondents.

\section{The effect of Age on Agricultural Indigenous Knowledge}

The study further sought to find out whether there is any association between age and types of agricultural indigenous knowledge. A cross tabulation and Chi square analysis was performed on age and types of Agricultural Indigenous Knowledge required by respondents. Their responses are indicated in table below.

Table 4: Age and types of Agricultural Indigenous Knowledge.

\begin{tabular}{|c|c|c|c|c|c|c|c|c|c|}
\hline \multirow{2}{*}{ Types of IK } & \multicolumn{5}{|c|}{ Age(years) } & \multirow{2}{*}{$\begin{array}{l}\text { Total } \\
\text { (in \%) }\end{array}$} & \multicolumn{3}{|c|}{ Chi-Square Tests } \\
\hline & $20-30$ & $31-40$ & $41-50$ & $51-60$ & $\begin{array}{l}\text { above } \\
60\end{array}$ & & $\begin{array}{l}\text { Pearson Chi- } \\
\text { Square }\end{array}$ & $\mathrm{df}$ & Sig. \\
\hline Planting season & 154 & 162 & 171 & 85 & 70 & 65 & 34.612 & 4 & .000 \\
\hline Pest Control & 129 & 133 & 137 & 114 & 59 & 58 & 49.571 & 4 & .000 \\
\hline Marketing of farm produce & 99 & 186 & 154 & 105 & 121 & 68 & 106.922 & 4 & .000 \\
\hline Crop processing & 112 & 140 & 99 & 82 & 44 & 48 & 29.688 & 4 & .000 \\
\hline Shifting cultivation & 103 & 139 & 93 & 77 & 40 & 46 & 34.122 & 4 & .000 \\
\hline Improving soil fertility & 131 & 174 & 116 & 91 & 24 & 54 & 117.846 & 4 & .000 \\
\hline Information on rainfall pattern & 116 & 134 & 128 & 81 & 44 & 51 & 31.487 & 4 & .000 \\
\hline Market Information & 78 & 147 & 143 & 96 & 110 & 58 & 97.700 & 4 & .000 \\
\hline $\begin{array}{l}\text { Information on different } \\
\text { agricultural program }\end{array}$ & 84 & 103 & 86 & 93 & 23 & 39 & 74.351 & 4 & .000 \\
\hline Soil classification & 121 & 103 & 88 & 92 & 25 & 44 & 70.234 & 4 & .000 \\
\hline Irrigation & 45 & 108 & 96 & 66 & 22 & 34 & 76.274 & 4 & .000 \\
\hline Agricultural tools & 98 & 131 & 101 & 73 & 40 & 45 & 26.635 & 4 & .000 \\
\hline Land preparations & 155 & 162 & 131 & 100 & 54 & 61 & 39.848 & 4 & .000 \\
\hline
\end{tabular}

The data was subjected to chi-square analysis to find out whether there any association between age and types of agricultural knowledge. It can be seen from the table that the association between age and types of agricultural indigenous knowledge required by small scale farmers is statistically significant since $p<0.05(p=0.00)$ for all types of types of agricultural knowledge. 
Therefore, we can say that there is statistically significant effect of age on types of agricultural indigenous knowledge required by small scale farmers.

The effect of education on types of ICT tools used by small scale farmers.

Furthermore, a cross tabulation and Chi square analysis was performed on level of education and types of ICT tools and services used by respondents. This test was performed in other to find out whether there exist any statistical association between level of education and the types of ICT used. The result is summarized in the table below

Table 5: Level of education on types of ICT tools used.

\begin{tabular}{|c|c|c|c|c|c|c|c|c|}
\hline \multirow{2}{*}{ ICT Tools and Services } & \multicolumn{5}{|c|}{ Level of education } & \multicolumn{3}{|c|}{ Chi-Square Tests } \\
\hline & $\begin{array}{l}\text { No formal } \\
\text { education }\end{array}$ & $\begin{array}{l}\text { Basic } \\
\text { education }\end{array}$ & Secondary & Tertiary & Total & $\begin{array}{l}\text { Pearson } \\
\text { Square }\end{array}$ & $\mathrm{df}$ & Sig. \\
\hline Computers & 0 & 21 & 2 & 14 & 4 & 70.319 & 3 & .000 \\
\hline Internet & 0 & 0 & 1 & 14 & 2 & 174.579 & 3 & .000 \\
\hline Email & 0 & 0 & 1 & 4 & 0.5 & 42.060 & 3 & .000 \\
\hline CD-ROM databases & 0 & 0 & 0 & 0 & 0 & & & \\
\hline GlS & 0 & 0 & 0 & 0 & 0 & & & \\
\hline Telephone/Fax & 0 & 14 & 0 & 23 & 4 & 97.700 & 3 & .000 \\
\hline Mobile phone & 233 & 357 & 136 & 37 & 77 & 53.756 & 3 & .000 \\
\hline Television & 100 & 167 & 100 & 35 & 59 & 70.234 & 3 & .000 \\
\hline Video & 37 & 76 & 23 & 26 & 16 & 76.274 & 3 & .000 \\
\hline Radio & 225 & 372 & 152 & 38 & 79 & 26.635 & 3 & .000 \\
\hline Precision Agriculture & 0 & 0 & 0 & 0 & 0 & & & \\
\hline
\end{tabular}

The results show that at various Chi-Square values with $3 \mathrm{df} p<0.05(p=0.00)$ there is an association of education and all types of ICT tools and services. We can therefore deduced that there a significant effect of the level of education on types of ICT tools and services available to respondents since $p<0.05$

This study confirms an earlier study by Frempong (2008) which found out that education plays an important part in the adoption and use of ICT services. ICTs services are knowledge intensive and therefore some level of literacy is required to ensure effective utilization of the technology.

The effect of Gender on agricultural indigenous knowledge small scale farmers.

The study sought to explore whether there is a statistically significant association between the gender of respondents and the agricultural indigenous knowledge farmers practiced. A cross tabulation and Chi square analysis was performed and the result shown in table 6 
Table 6: Gender on types of Agricultural Indigenous Knowledge.

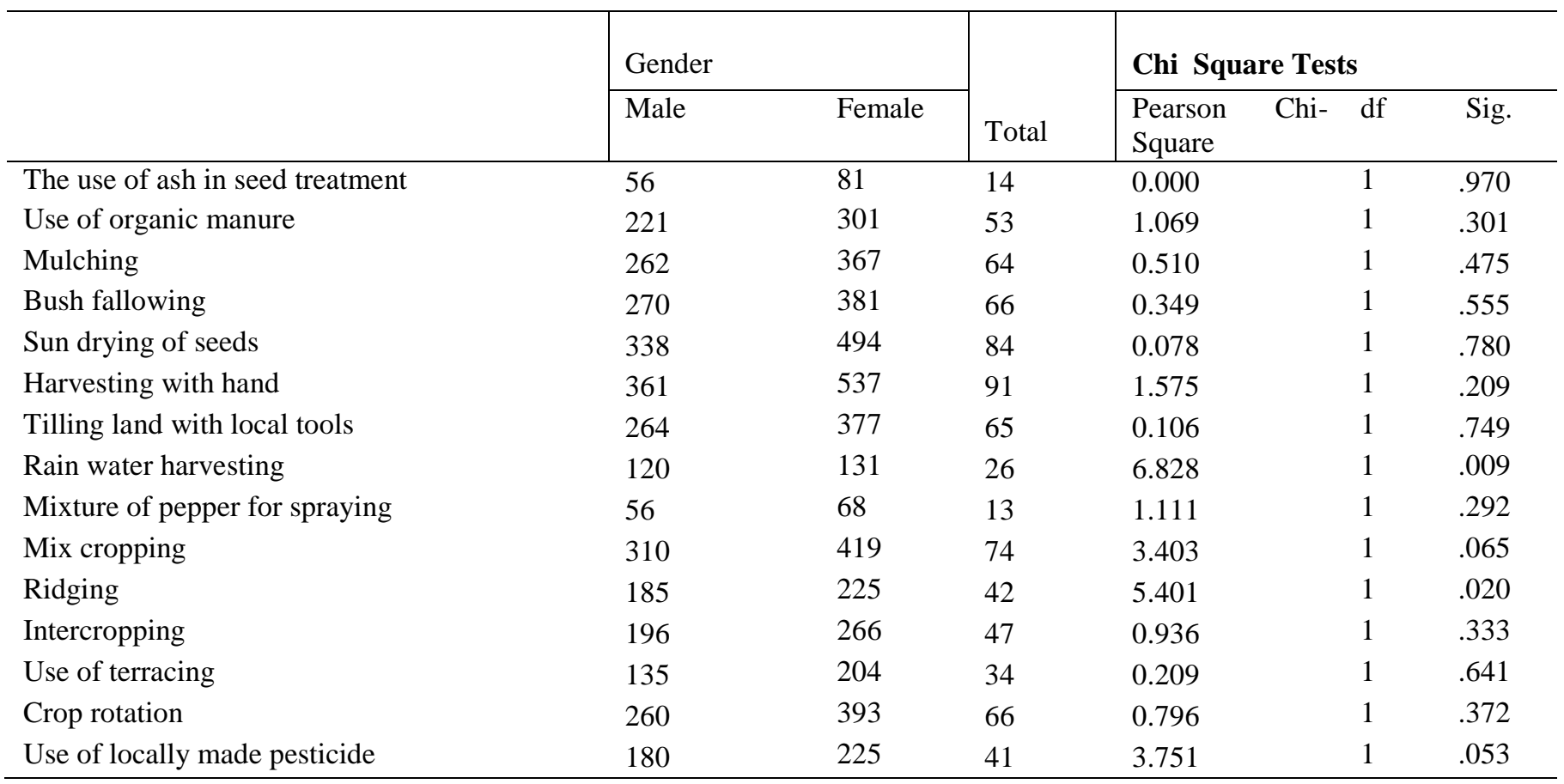

The table shows significance values for all the various chi-square values with 1 degree of freedom (df) is greater than the set significant value of $0.05(p>0.05)$ except the value for rain water harvesting which is less than 0.05 . Therefore, statistically, there is a significant association between gender and rainwater harvesting, but there is no statistically significant association between gender and the rest of the IK practice stated by respondents. This confirms studies by Acharya and Bennett (1983), UNICEF (1987) and Timsina et al..,(1989) which revealed that men usually take responsibility for land preparation, ploughing and harvesting while women undertake the collection of folder and feeding of livestock, kitchen gardening, collection of organic manure.

\section{Conclusions}

Nowadays, ICTs can help to document and disseminate indigenous knowledge. Digital preservation and the promotion of local knowledge provide a means for isolated communities to become part of the global information society. Based on the findings from the study we can draw a conclusion that age has effect on agricultural indigenous knowledge required by small scale farmers. Additionally, the study concluded that education has a significant effect of on the types of ICT tools and services used by small scale farmers. Also gender has no statistical significance effect of on the type of AIK practice by respondents.

\section{Reference}

Acharya and Bennett (1983) Women and the subsistence sector: economic participation and Household - decisionmaking in Nepal. World Bank Staff Working Papers No 526.Washington DC.

Alavi, M. and Leidner, D., 2001, knowledge management and knowledge management conceptual foundations and research issues', MIS review, 25(6), 95-116

Anderson, R. Jock; Feder, Gershon. 2004. "Agricultural extension: good intentions and hard realities". The World Bank research observer. -- Vol 19, no.1 (Spring 2004), pp. 41-60.

Anderson, J.R. and Feder, G. (2007), “Agricultural extension”. In: R. E. Evenson and P. Pingali(eds.) Agricultural development: Farmers, farm production and farm markets. Handbook of agricultural economics, Vol.3, (Amsterdam: Elsevier), 2343-78.

Bultum, A. G. (2014). Factors Affecting Adoption of Electronic Banking System in Ethiopian Banking Industry. Journal of Management Information System and E-Commerce, 1(1), 1-17

FAO, (2006), The Internet and Rural and Agricultural Development - An Integrated Approach Food and Agriculture Organization, Rome, http://www.fao.org/docrep/w6840e/w6840e05.htm (Accessed on 16/01/18)

Gefen, D. \& Straub, D. (1997). Gender differences in the perception and use of e-mail. An Extension of the technology acceptance model. MIS Quarterly, 21 p389-400 
Hart, Tim \& Mouton, Johann. (2005). Indigenous Knowledge and its relevance for agriculture: a case study in Uganda. Indilinga- African Journal of Indigenous Knowledge Systems. 4. 249-263.

Jensen, A.L., \&Thysen, I. (2003). Agricultural information and decision support by SMS. Proceedings of the EFITA 2003 Conference (pp. 286 - 292). Hungary: Debrecen.

Mettrick, H. (1993). Development-oriented research in agriculture: an ICRA textbook. Wageningen: The International Centre for Development-Oriented Research in Agriculture (ICRA). Michigan State University and Muguga South Centre, Kenya Agricultural Research Institute (KARI) Office of Agricultural Economics (OAE)(2009).The study of farmers' poverty. Retrieved July 27, 2017 from http://www.oae.go.th/ewtnews.php?nid=4431\& filename index

Neven, D., Reardon, T., Chege, J., Michael M. Odera, MM., Dave Weatherspoon, D., Ondieki- Mwaura, F., (2005), The Rapid Rise of Supermarkets in Kenya: Impact on the Fresh Fruits and Vegetables Supply System, A Joint Publication of Partnerships for Food Industry Development - Fruits and Vegetables (PFID-F\&V)

Scoones, I. \& Thompson, J. (eds) (1994). Beyond farmer first: rural peoples' knowledge, agricultural research and extension practice. London: Intermediate Technology Publications.

Timsina, D., Timsina, J. and Chhetry M.B. (1989) Women's role in Nepalese farming systems: a comparative study of a hill and an inerter farming systems site, Working Papers on Women in International Development No. 193, Michigan State University, Office of Women in International Development.

UNICEF (1987) Children and Women of Nepal: a situation analysis. UNICEF, Kathmandu.

Van Veldhuizen, L., Waters-Bayer, A., Ramirez, R., Johnson, D.A. \& Thompson, J. (eds) (1997). Farmers' research in practice: lessons from the field. London: Intermediate Technology Publications

Warren MF (2003), Farmers and the Internet, six years on. Paper presented at the EFITA conference, Hungary

Warren, M. (2004). Farmers online: drivers and impediments in adoption of Internet in UK agricultural businesses. Journal of Small Business and Enterprise Development, 11(3), 371 - 381.

Zijp, W. (1994), Improving the transfer and use of agricultural information a guide to Information Technology. Washington DC: World Bank. 